\title{
SOUTHERNMOST HIGH MOUNTAIN LAKES IN EUROPE (SIERRA NEVADA) AS REFERENCE SITES FOR POLLUTION AND CLIMATE CHANGE MONITORING.
}

\author{
R. Morales-Baquero1, P. Carrillo', L. Cruz-Pizarro ${ }^{2}$ and P. Sanchez-Castillo ${ }^{3}$ \\ 1. Departamento de Biología Animal y Ecología, Fac. Ciencias, Universidad de Granada. Spain. \\ 2. Instituto del Agua, Universidad de Granada. Spain. \\ 3. Departamento de Biología Vegetal, Fac. Ciencias, Universidad de Granada. Spain.
}

Keywords: High mountain lakes, Regional limnology, Sierra Nevada, Spain.

\begin{abstract}
This paper summarize, from a regional limnology point of view, some of the identifying characteristics of Sierra Nevada high mountain lakes, as a result of the studies carried out by the limnology group of the University of Granada since 1975. A overall narrow variability in the morphological, physical and chemical characteristics of this lakes seems to appear as a consequence of a smaller and more homogeneous distribution area than high mountain lakes of other mountain ranges (i.e. the Alps) cover. The position of Sierra Nevada, far away from industrialized areas, keep their water bodies free of air pollution which reflects in the relatively high levels of alkalinity compared with other mountain lakes under acidification processes (i.e. Norwegian ones). Likewise, their southern position makes the Sierra Nevada high mountain lakes ideal reference sites for climate change monitoring. The homogeneity in their abiotic environment is responsible of a limited biological diversity of their planktonic communities. The phytoplankton is dominated by nanoplanktonic species and the zooplankton is only composed by 20 rotifer species, 8 cladocerans and 5 copepods. All these characteristics underline the interest of Sierra Nevada lakes as subject of scientific research both applied as in a purely theoretical plane.
\end{abstract}

\section{INTRODUCTION}

Small high mountain lakes, under severe physical conditions, have for long been recognized as unique inland waters ecosystems. Properties linked to a fluctuating climate, short growing seasons, low thermal stability, high irradiance and, usually, low nutrient levels, in turn due to small sized watersheds and weak human influence, are all responsible for their relatively simplified biological communities, thus being suitable sites to study the basic relationships between their components.

Their, at times, remote location can explain their knowledge to be far from desirable, and, because of their mostly glaciar origin, the bulk of the available information comes from septentrional and central mountains of the northern hemisphere where the glacial activity had its maximun impact (TONOLLI \& TONOLLI, 1951; PENNAK, 1955; THOMASSON, 1956: ANDERSON, $1974 \ldots$.. Toward southern latitudes, as higher altitudes are needed to observe such effects, areas suited to having comparable lakes became much more scarce and isolated.

The Sierra Nevada $\left(37^{\circ} \mathrm{N}\right)$, is the most southerly mountain system in Europe reaching altitudes higher than 3000 $\mathrm{m}$, and embraces in its highest zone some 50 small water bodies, whose primary interest as reference sites in any comparison study concerning climatic factors and pollution background levels, reveals obvious.

Appart from some spot data coming from studies by LÖFFLER (1974) and GONZALEZ-GUERRERO (1975), an integrated research program was started by MARTINEZ (1975) at the limnology group of the University of Granada. In this paper we summarize some of the identifying characteristics of these lakes from a regional limnology point of view.

\section{LIMITED VARIABILITY AMONG LAKES.}

The glacial action in the Sierra Nevada was limited to the upper areas, close to the crest lines, and so most of the 
lakes lay in a narrow strip of between approximately 2800 and 3050 m.a.s.l. whithin a distance of just under $20 \mathrm{~km}$. This sharply contrast with the greater geographical area and ranges of altitudes they spread out in the Pyrenees (1000-2800 m, NUSSBAUM, 1931) or in the Alps (e.g. 900-3000 m, MOSSELLO, 1984), and having important consequences, such as in relation with weathering rates in the watersheds and therefore in the chemical characteristics of the lakes at different altitudes (ZOBRIST \& DREVER, 1990).

The bedrock underlying ihese lakes is also relatively homogeneous. It is mainly siliceous and dominated by different kind of micaschists, in addition to some brechoid marbles (PUGA, 1971), although the differences in mineral types composition over the individual watershed areas do not seem to reflect on the chemical characteristics of the waters (table 1).

The lakes in Sierra Nevada are small in size (from a few dozen of square meters to a maximun of ca. $20,000 \mathrm{~m}^{2}$ ), and shallow (maximum depths ranging from less than $1 \mathrm{~m}$ up to $12 \mathrm{~m}$ ). They remain frozen from October or November until May or June, and their small size brings about rapid gains and loss in heat. The average annual heat budget never exceeds

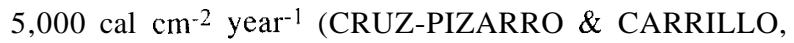
1990) and appear to be very sensitive to changes in air temperature. In fact the mean of the maximum temperatures in lake La Caldera over a decade (seventies-eighties), rose in about 4 C (CRUZ-PIZARRO, 1981; CARRILLO, 1989), coinciding with periods of cold and warm average overall temperatures in the northern hemisphere respectively (JONES et al., 1986).

Because of their geographical position they are exposed to winds blowing from the South or Southwest, that is, from zones of low industrialization (North Africa), and therefore the atmospheric pollution is of little importance. Nevertheless, these winds rather often carry dust from the Sahara, which sporadic rains bring down. The lakes respond rapidly in the form of swift increases in the plankton chlorophyll levels (and declines in the visibility of the Secchi disk) after each occasion (CARRILLO et al., 1990) (fig. 1). These allochtonous inputs are an important source of alkalinity in high mountain lakes (PSENNER \& NICKUS, 1986), which all the Sierra Nevada lakes undergo homogeneously, given their small geographical area.

The similarity of these conditions leads to limited variation among chemical characteristics. As such, the average conductivity values in a survey of 31 lakes (carried out in the Summer of 1991) are between 8 and $77.1 \mu \mathrm{S} \mathrm{cm}-1$, values quite similar to those for conductivity of Alpine lakes

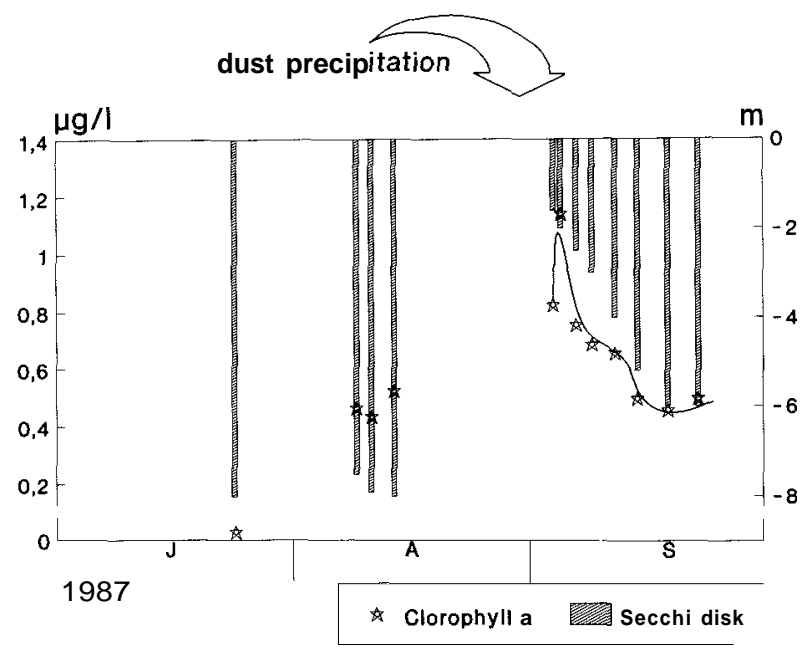

Figure 1. Time course of chlorophyll-a and transparency in lake La Caldera after a dusty rain episody.

with less mineralization, which are the majority in that mountain system, where also the conductivity exceeds 1,200 $\mu \mathrm{S} \mathrm{cm}^{-1}$ (MOSELLO, 1984). Similarly, in the lakes of the Sierra Nevada, the total alkalinity was consistently greater than $0.05 \mathrm{meq}^{1^{-1}}$ and rarely surpassed 0.4 meq $\mathrm{I}^{-1}$ (fig. 2). This range is considerably smaller than that found in the Alps, where the alkalinity can reach more than 3.5 meq $\mathrm{1}^{-1}$ (MOSELLO, 1984). However, it implies a considerable bicarbonate buffer capacity, bearing in mind the nature of the bedrock, compared with lakes in the Alps and Norwegian mountains where $55 \%$ and $95 \%$, respectively, have a total alkalinity of less than $0.2 \mathrm{meq}^{1-1}$ (WATHNE et al., 1990) with an important number of lakes showing negative alkalinity. The Sierra Nevada, therefore, differs from those areas subjected to acidification processes, and consequently, the $\mathrm{pH}$ of the Sierra Nevada lakes, although lightly acidic in the majority of the lakes ( $69 \%$ of the waters studied have a $\mathrm{pH}$ of between 6 and 7), never falls below 5.5 (fig. 2).

On the other hand the homogeneity among chemical characteristics allows other physically mediate relationship (to some extent related to lake size) to become apparent. This is the case with the oxygen content, for which the inverse dependence upon temperature can be seen in the average values of both variables for all the lakes (fig. 3 ).

\section{A REDUCED BIOLOGICAL DIVERSITY.}

Like other mountain systems in Europe (TONOLLI \& TONOLLI, 1951; PEJLER, 1965; PECHLANER, 1967; 


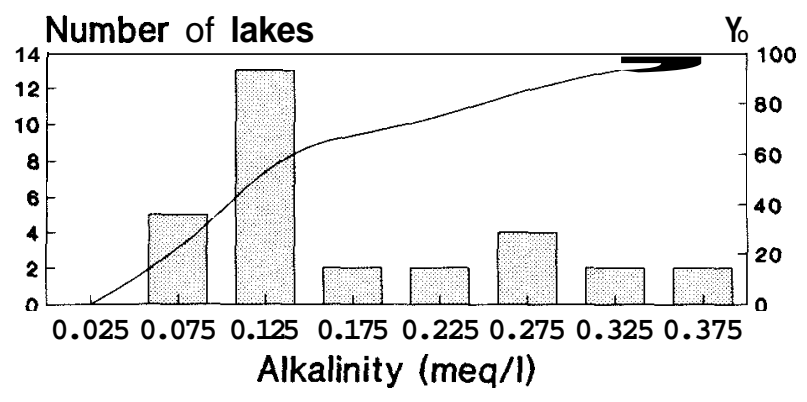

Number of lakes

Cumulative frequency

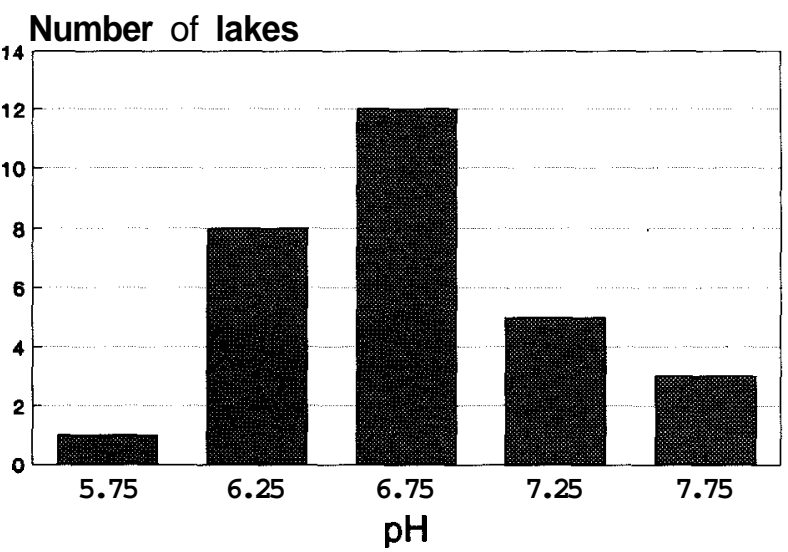

Figure 2. Frequency distribution ol Sierra Nevada lakes according to their alkalinity and $\mathrm{pH}$ levels (values are midpoints of intervals).

CAPBLANCQ, 1972; MIRACLE, 1978), the plankton of the Sierra Nevada is composed by species having a wide geographical distribution. Except for the Chrysnphyceae Chromulina nevadensis (SANCHEZ-CASTILLO, 1987a) and the Rotifer Lepadella quinquecnstata nevadensis (MORALES-BAQUERO, 1987a), which has been described in the Sierra Nevada, or Hexarthra bulgarica, considered to be a typical high mountain rotifer (DUMONT, 1980; CRUZPIZARRO \& MORALES-BAQUERO, 1987), no other is a rare or endemic species. Thus the high mountain plankton of the Sierra Nevada is not essentially distinguishable from that found in other regions at lower altitudes. Nevertheless more species of rotifers can be found in common between the Sierra Nevada and Swedish Lapland than between the Sierra Nevada and the Alps or the Pyrenees (MORALESBAQUERO, 1985).

Qualitative studies of phytoplankton (SANCHEZCASTILLO, 1988) reveal species belonging to the most important algal groups: Cyanophyceae, Dinophyceae, Euglenophyceae, Chrysophyceae, Diatomophyceae, Chlorophyceae and Zygophyceae (fig. 4), the last three, together with the blue-green algae, being the most representatives. Only three species are common to most of the lakes: Nostoc kihlmanii, Meridion circulare and Cymbella minuta.

Diatoms and desmids, the taxonomic groups best represented, are most abundant in lakes where important epipelon communities develop. This benthic community consists fundamentally of groups clearly capable of motility, such as the diatoms, chiefly represented by Frustulia rhomboides, Navicula radiosa and Nitzschia hantzchiana. Another important group is that of the desmids, where Euastrum oblongum, E. verrucosum, Staurastrum punctulatum and $S$. spongiosum, among others, are the most common taxa. These species, although accidentally found in plankton, develop optimally in benthic communities (epipelon), and become very important in these oligotrophic lakes with transparent waters. The shallowness of most of these lakes is one of the principal factors that allow the continous resuspension of these organisms.

These tycoplanktonic species never develop important planktonic populations (MARTINEZ, 1975, 1977; SANCHEZ-CASTILLO et al., 1989). Most of the phytoplankton biomass is devoted by nanoplanktonic organisms, motile or not, which reflects the strong oligotrophic character of these waters (REYNOLDS, 1984; ROTT, 1988; TRIFONOVA, 1989). The most important species are included in three fundamental biological types: non motile cells; flagelate cells and cells of epizoic origin.

Non-motile cells. These are spherical or ellipsoidal organisms in which the high surface/volume ratio enables them to make effective use of the scarce resources of the environment. Among those with a sphericall morphology, there is only one important small chloreloid taxon. Species with an

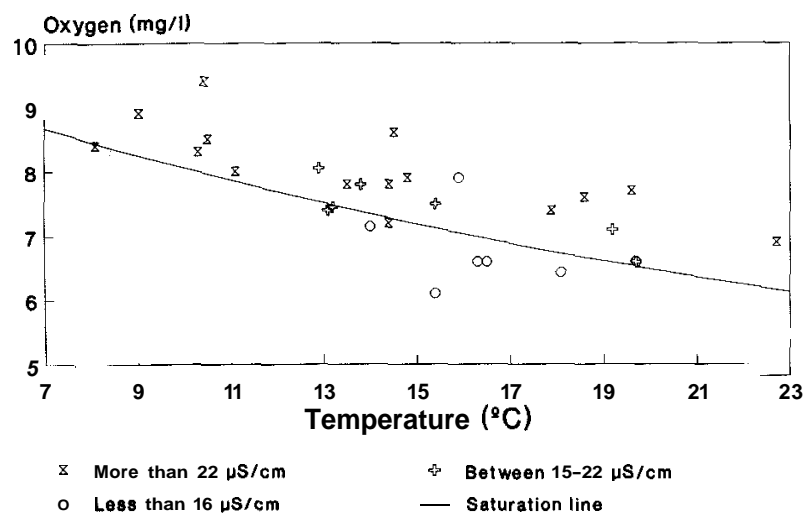

Figure 3. Oxygen-temperature relationships of Sierra Nevada lakes (values are averages for the ice-free period in each lake). From MORALES-BAQUERO et al. (1986). 
Table 1. Morphometric characteristics (lenght, width and depth, in $\mathrm{m}$ ), basin rock mineral components, nutrients and chlorophyll-a concentrations of the investigated lakes.

\begin{tabular}{|c|c|c|c|c|c|c|c|c|}
\hline & $\mathrm{L}$ & $\mathrm{W}$ & $\mathrm{D}$ & $\begin{array}{c}\text { Main } \\
\text { Minerals }\end{array}$ & $\begin{array}{l}\mathrm{PO}, \\
(\mu \mathrm{g} / 1)\end{array}$ & $\begin{array}{c}\mathrm{NO}_{3} \\
(\mu \mathrm{g} / 1)\end{array}$ & $\begin{array}{c}\mathrm{SiO}_{2} \\
(\mathrm{mg} / 1)\end{array}$ & $\begin{array}{l}\text { Chl.-a } \\
(\mu \mathrm{g} / 1)\end{array}$ \\
\hline Dilar 1 & 4 & 3 & 1.0 & $\mathrm{G}, F, C, B$ & & & & 0.6 \\
\hline Dilar 2 & 17 & 8 & 1.0 & $\mathrm{G}, \mathrm{F}, \mathrm{C}, \mathrm{B}$ & & & & 0.3 \\
\hline Virgen 1 & 50 & 12 & 1.3 & $\mathrm{G}, \mathrm{F}, \mathrm{C}, \mathrm{B}$ & 3.117 .6 & $27.5 \mathrm{k} 24.5$ & $0.93 \pm 0.1$ & 0.4 \\
\hline Virgen 2 & 20 & 10 & 0.8 & $\mathrm{G}, \mathrm{F}, \mathrm{C}, \mathrm{B}$ & $2.1 \mathrm{I} 5.1$ & $12.6 \mathrm{I} 13.3$ & 0.6610 .1 & 2.2 \\
\hline Yeguas & 90 & 40 & 8.0 & $\mathrm{G}, \mathrm{F}, \mathrm{C}, \mathrm{B}$ & $3.1 \mathrm{k} 7.6$ & $16.51 \mathrm{r} 15.6$ & 1.3410 .4 & 2.2 \\
\hline Lanjarón 3 & 65 & 25 & 1.5 & & & & & 1.9 \\
\hline Lanjarón 2 & 15 & 5 & 1.0 & & & & & 1.1 \\
\hline Lanjarón 1 & 40 & 25 & 4.0 & & & & & 1.1 \\
\hline Cuadrada & 30 & 18 & 4.8 & & & & & 0.5 \\
\hline Caballo & 70 & 40 & 4.0 & & & & & 0.3 \\
\hline Mosca & 75 & 35 & 2.8 & $\mathrm{~F}, \mathrm{~A}, \mathrm{C}, \mathrm{M}$ & & & & 2.2 \\
\hline Aguas Verdes & 50 & 30 & 2.8 & $\mathrm{G}, \mathrm{F}, \mathrm{C}, \mathrm{B}$ & $3.5 \mathrm{k} 6.1$ & 12.0125 .8 & $0.59 \mathrm{k} 0.1$ & 0.6 \\
\hline Caldera & 190 & 140 & 12.0 & $\mathrm{~F}, \mathrm{~A}, \mathrm{C}, \mathrm{M}$ & $2.7 \pm 4.9$ & $50.8 \mathrm{k} 38.2$ & $0.31 \mathrm{I} 0.1$ & 0.2 \\
\hline Majano & 80 & 60 & 0.8 & $\mathrm{~F}, \mathrm{~A}, \mathrm{C}, \mathrm{M}$ & 10.9116 .3 & $24.6 \mathrm{k} 46.6$ & 1.2910 .3 & 2.0 \\
\hline Gemela & 25 & 20 & 0.3 & $\mathrm{~F}, \mathrm{~A}, \mathrm{C}, \mathrm{M}$ & 13.3.18.4 & $37.8 \mathrm{k} 36.1$ & 0.8510 .2 & 1.4 \\
\hline Larga & 210 & 80 & 7.0 & & & & & 0.3 \\
\hline Rio Seco Superior & 20 & 15 & 2.0 & $\mathrm{G}, \mathrm{F}, \mathrm{C}, \mathrm{B}$ & $5.21 \mathrm{r} 8.2$ & $31.0 \pm 47.4$ & 0.5410 .4 & 0.9 \\
\hline Rio Seco & 80 & 30 & 2.5 & $\mathrm{G}, \mathrm{F}, \mathrm{C}, \mathrm{B}$ & 13.714 .4 & 37.4 .130 .2 & $0.66 \pm 0.1$ & 0.5 \\
\hline Rio Seco Inferior & 20 & 15 & 1.0 & $\mathrm{G}, \mathrm{F}, \mathrm{C}, \mathrm{B}$ & $35.1 \mathrm{k} 14.9$ & $36.1 \mathrm{k} 34.1$ & $0.77 \pm 0.4$ & 2.8 \\
\hline Mirador & 20 & 10 & 0.5 & $\mathrm{G}, \mathrm{F}, \mathrm{C}, \mathrm{B}$ & & & & 1.8 \\
\hline Siete Lagunas 1 & 70 & 50 & 2.5 & $\mathrm{D}, \mathrm{E}$ & & & & 0.9 \\
\hline Siete Lagunas 2 & 65 & 60 & 3.5 & $\mathrm{D}, \mathrm{E}$ & & & & 0.5 \\
\hline Siete Lagunas 4 & 40 & 20 & 0.5 & $\mathrm{D}, \mathrm{E}$ & & & & 0.7 \\
\hline Siete Lagunas 5 & 30 & 20 & 2.0 & $\mathrm{D}, \mathrm{E}$ & & & & 1.7 \\
\hline Siete Lagunas 7 & 150 & 40 & 1.0 & $\mathrm{D}, \mathrm{E}$ & & & & 0.8 \\
\hline Peñón Negro & 100 & 80 & 2.0 & $\mathrm{D}, \mathrm{E}$ & & & & 4.1 \\
\hline Caldereta 1 & 40 & 40 & 3 & & & & & 0.2 \\
\hline Caldereta 2 & 35 & 30 & 3.0 & & & & & 0.3 \\
\hline Caldereta 3 & 50 & 40 & 2.5 & & & & & 0.8 \\
\hline Vacares & 80 & 60 & 8.0 & & & & & 0.5 \\
\hline Juntillas & 70 & 30 & 1.5 & & & & & 0.5 \\
\hline
\end{tabular}

A, anphybolite; B, biotite; C, quartz; F, feldespar; D, distene; E, estaurolite; M, marbel; G, graphyte 


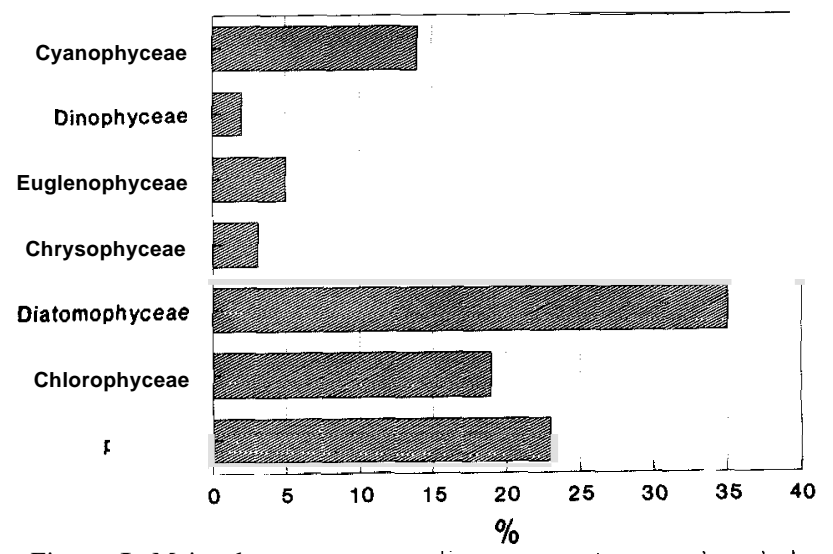

Figure J. Main algae groups (qualitancic salmpless fou the whole Sierra Nevada lakes, during the ice-free period.

ellipsoidal morphology, straight or curved. such as Oocystis lacustris and Cyanarcus sp. are common in various lakes. If indeed the morphology of this last species diverges markedly from the characteristics already mentioned, the curved form of the cell seems to be an excellent adaptation to the planktonic environment. In fact, this biotype is found in other planktonic algae, most of them coming from strongly eutrophic environments, such as many species of Monoraphidium.

Flagellate cells. Also small in size, are widely represented in high mountain lakes (PECHLANER, 1967; CAPBLANCQ, 1972; ROTT, 1988). By flagellar movement these are able to break up gradients of microdistribution of nutrients. Such movements and the diferential day-night predation by zooplankton are responsible of daily migrations hardly understood so far (CARRILLO et al., 1991a). Chromulina nevadensis, Ochromonas sp., Rhodomonas minuta and various species of Chlamydomonas and Chlorogonium belong to this group of taxa. The mixotrophic character shown by many of these flagellate algae is specially obvious in $C$. nevadensis, which show an enormous morphological variability among lakes, well related with the trophic level of the environment (CARRILLO et al., 1991b). fig. 5, shows the three most common morphotypes observed for this species, beginning with the largest in size, which have a well developed chromatophora, next the intermediate size and finally coming to a form with dendricules, which are specially visible at the basal zone of the cell. Various authors have observed this last situation in different species of the genus (C. delacarlica, C. flavicans, C. frigidofila and C. skujae).

Cells of epizoic origin. These are organisms of greater size which, taking advantage of their epizoic development, colonize the planktonic environment up to an important degree. In these lakes at least two epizoic organisms have been detected whose different cellular stages produce important planktonic populations (SANCHEZ-CASTILLO, 1986). This includes Korshikoviella gracilipes and Chlorangiella pygmaea, two green algae which develop on cladocerans (Daphnia pulex and Alona rectangula respectively) in at least five of these lakes. Both algae, once the colonization is under way, begin to produce a great quantity of zoospores which become an important part of the phytoplankton. This epizoitism, which can be considered to be symbiotic, gives the alga mobility without expending energy. making possible the exploitation of different lacustrine environments. $D$. pulex and $A$. rectangula have the advantage of an important food source, since from the beginning of their development both produce a large amounts of zoospores.

The tendency in colonizing the planktonic environment by the different cellular stages is exemplified in fig. 6, where chlorangioid cells and zoospores comprise more than $60 \%$ of the community during the month of September. Other juvenile phases which do not reach a consistent cladoceran fixation also became part of the plankton, although in a much lower proportion. Some of these phases, especially the ankiroid in $K$. gracilipes (SANCHEZ-CASTILLO, $1987 \mathrm{~b}$ ) are almost identical to certain planktonic taxa, and therefore can develop, without problems of sinking, suspended in the water. It would be reasonable, in fact, to expect the existence of some neotenic process which might link different generic taxa, planktonic and epizoic, in this group of green algae (SANCHEZ-CASTILLO, 1991).

Concerning to the zooplankton, the severity of the physical environment in the Sierra Nevada manifests itself in a low number of species: 20 rotifers; 8 cladocerans and 5 copepods (disregarding sporadic ones) and, also, in the simplicity of the plankton trophic webs, as shown by the scarcity of predators,
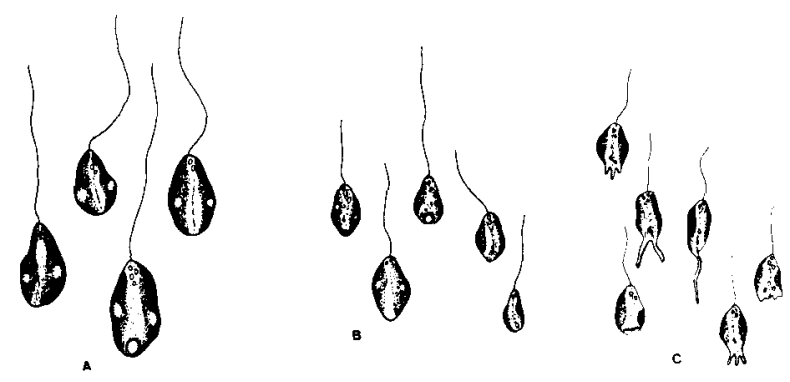

Figure 5. ( homalima neladems. mospholypes in lake La Caldera. A) Greatest sized cells showing a well differentiated plastids; B) intermediate size: C) smaller sized cells with dendricules on basal zone. 


\section{Ice Free Period}

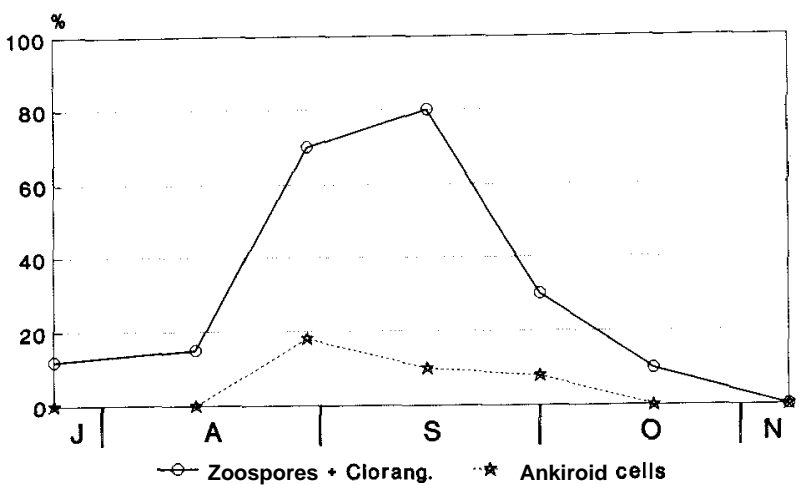

Figure 6. Presence of different planktonic stages of Korshikoviella gracilipes in the plankton community from lake Rio Seco.

restricted to few numerically unimportant cyclopoid species. This simplicity is typical of other mountain lakes and also of northern systems (PEJLER, 1983).

A distinguisable feature for the zooplankton communities of these lakes is the recurrence in the species composition. As can be seen in fig. 7, there are few pairs of species which do

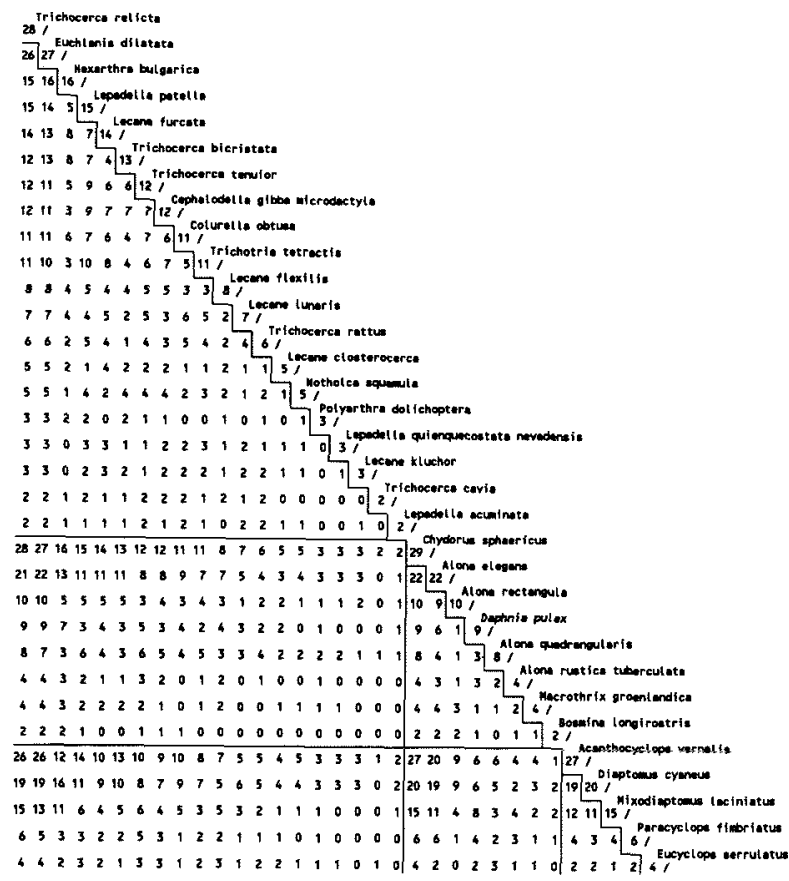

Figure 7. Zooplankton species from 30 laken of the Sierra Nevada, with indication of the total number of lakes in which each species was found (closer number to specie names), and number of lakes where each pair of species occur (from MORALES-BAQUERO, 1985 and HERNANDEZ-MARQUEZ, 1986). not coexist together in, at least, one lake. This is consistent with the forementioned homogeneity among the physical characteristics of the lakes and sharply contrasts with the much lower levels of coincidence between the species which can be found in other regions such as the Tyrol (SCHABER, 1988).

In each taxonomic group the majority of the species come from benthic or littoral habitats, and indeed only the following species can be considered to be actually planktonic ones: Hexarthra bulgarica, Notholca squamula and Polyarthra dolichoptera among the rotifers; Daphnia pulex and Bosmina longirostris among the cladocerans; and Diaptomus cyaneus and Mixodiaptomus laciniatus among the copepods.

The predominance of species from non-pelagic habitats is of course related to the small size and shallowness of the water bodies, as the importance of the strictly pelagic zones is very small relative to the significance of the benthos and/or the littoral one. Nevertheless, it is not only the size of the lakes which determines the predominance of planktonic species in the pelagic communities. An analysis of the distribution species (MORALES-BAQUERO, 1987b) and the composition patterns in the rotifer communities (MORALES-BAQUERO et al., 1989) indicates a relationship between the nature of these communities, the total concentration of salts in the lakes (in spite of the general small range of conductivity) and the development of littoral vegetation. As can be seen in fig. 8, the lakes with less conductivity have a lower number of species but a greater abundance of organisms per cubic meter, mainly due to $\mathrm{H}$. hulgarica.

As expected, species such as Acanthocyclops vernalis, Chydorus sphaericus or Euchlanis dilatata, all capable of

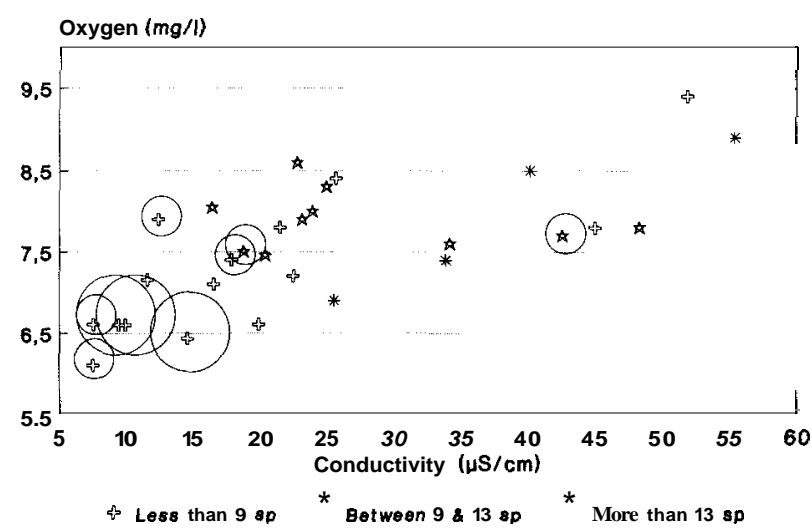

Figure 8. Conductivity-oxygen relationship of Sierra Nevada lakes (averaged values for the ice-free period in each lake) and number of rotifer especies founded. Great circles surround lakes with more than 70,000 org. $\mathrm{m}-3$, smaller ones those with intermediate densities $(10,000$ $-70,000$ org. m-3). Not encircled: lakes with less than 10,000 org. $m-3$. 
exploiting both the pelagic and the littoral zones, are within those with the greater distribution pattern among lakes (in fact, occurring in more than $90 \%$ of them), and offer an unique oportunity to analyze populations on well isolated and definite characteristics waters because of their comparable development squemes (only one abundance peak). In this way it has been possible to determine that the temperature account for only a low percentage of the variability in the average size of the individuals from different E. dilatata populations (about 30\%, MORALES-BAQUERO, 1989) and also that factors linked to the development of a population in a certain lake (food conditions, genetic isolation, etc.) play an important role in determining an individual's size. Similarly the estimates of secundary production for this species in different lakes was quite variable (MORALESBAQUERO et al., 1990); and, even more noticeable, the production rates ( $\mathrm{P} / \mathrm{B}$ for the growth season) covered practically the entire range of values that have been described for all the rotifer species (fig. 9).

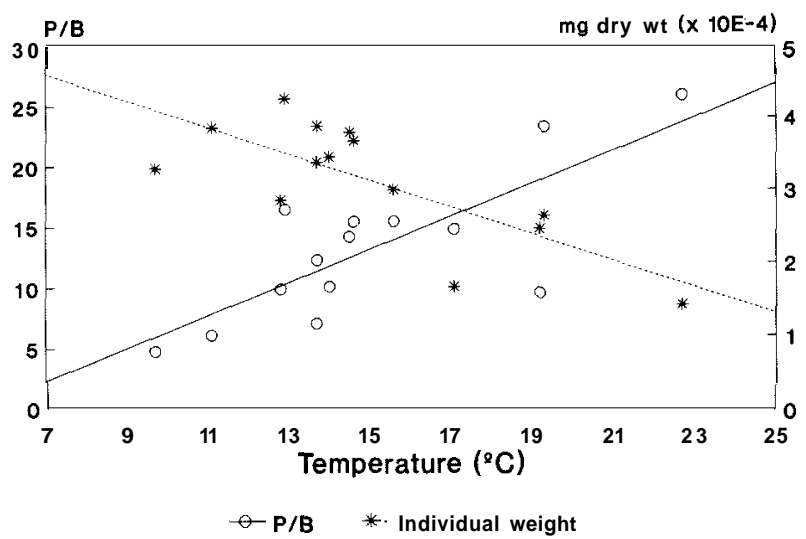

Figure 9. Individual mean weigth and growing season $\mathrm{P} / \mathrm{B}$ ratio of Euchlanis dilatata in relation wirh averaged ice-free period temperatures of each lake.

Much less is known about the bacterial communities (CANTERAS \& PEREZ, 1987) and on the benthic fauna of the lakes of the Sierra Nevada, for which data exist about the distribution of Quironomides (LAVILLE \& VILCHEZQUERO, 1986), Coleoptera (SAINZ-CANTERO \& ALBATERCEDOR, 1991) and Nematodes (OCAÑA, in prep.) The benthos is therefore an environment that demands further studies since its relative importance in the overall metabolism of these lakes could be very high. In addition, from a paleolimnological standpoint, the analysis of the sediments promises interesting results after registering modifications in the structure of communities associated with global climatic changes to which these waters seem to be sensitive.

\section{SUITABLE SITES.}

In conclusion, from the point of view of the regional limnology, the high mountain lakes of the Sierra Nevada appear to be homogeneous waters easely characterizable and whith low levels of pollution. Therefore these lakes are useful both as a reference sites in analyzing acidification in Europe, and as sensors of global climatic changes. In another sense, because of the narrow ranges of overall variation in lake characteristics are often covered by individual values, these lakes are ideals for comparative studies of processes determined by the specific parameters of each lake. This allows, among the other approaches, the study of not only factors which affect the distribution of species occupying the lakes, but also of forces structuring their communities. Thus these waters, as subjects of research, can also generate interest on a purely theoretical aspect.

\section{REFERENCES}

ANDERSON, R. S., 1974. Crustacean plankton of 340 lakes and ponds in and near the National Parks of the Canadian Rocky Mountains. J. Fish. Res. Bd. Canada 31: 855-869.

CANTERAS, J.C. \& L. PEREZ, 1987. The biochemical diversity of heterotrophic bacterial communities in high mountain lakes from Sierra Nevada. Acta Hydrobiol. 29(2): 137-147.

CAPBLANCQ, J., 1972. Phytoplankton et productivite primaire de quelques lacs d'altitude dans les Pyrenées. Ann. Limnol. 8(3): 231-321.

CARRILLO, P., 1989. Analisis de las interacciones tróficas en elplancton de un sistema oligotrófico. $\mathrm{Ph}$. D. Thesis. Universidad de Granada.

CARRILLO, P., L. CRUZ-PIZARRO \& R. MORALESBAQUERO, 1990. Effects of unpredictable atmospheric allochthonous input on the light climate of an oligotrophic lake. Verh. Internat. Verein. Limnol. 24: 97-101.

CARRILLO, P., P. SANCHEZ-CASTILLO \& L. CRUZ-PIZARRO, 1991a. Coincident zooplankton and phytoplankton diel migrations in a high mountain lake (La Caldera, Sierra Nevada, Spain). Arch. Hydrobiol. 122(1): 57-67. 
CARRILLO, P., L. CRUZ-PIZARRO \& P. SANCHEZCASTILLO, 1991b. Aportación al conocimiento del ciclo biológico de Chromulina nevadensis P. Sánchez. Acta Bot. Malacitana 16(1): 19-26.

CRUZ-PIZARRO, L., 1981. Estudio de la comunidad zooplanctónica de un lago de alta montaña (La Caldera, Sierra Nevada, Granada). Ph. D. Thesis. Universidad de Granada.

CRUZ-PIZARRO, L. \& R. MORALES-BAQUERO, 1987. Taxonomic and ecological notes on Hexarthra bulgarica canadensis from high mountain lakes and ponds in the Sierra Nevada (Spain). Hydrobiologia 147: 91-95.

DUMONT, H.J., 1980. Workshop on taxonomy and biogeography of rotifers. Hydrobiologia 73: 205-206.

GONZALEZ-GUERRERO, P., 1975. Los ficotopos de la Alta Alpujarra (Granada). Trab. Dep. Bot. Univ. Granada 3(1): 61-85.

HERNANDEZ-MARQUEZ, V.F., 1986. Crustáceos Planctónicos y Béntico-Litorales de las Lagunas de Sierra Nevada: Taxonomía, Distribución y Ecología. Memoria de Licenciatura. Universidad de Granada. 233 pp.

JONES, P.D., T.M.L. WIGLEY \& P.B. WRIGHT, 1986. Global temperature variations between 1861 and 1984 . Nature 322: 430- 434.

LAVILLE, H. \& A. VILCHEZ-QUERO, 1986. Les Chironomidés (Diptera) de quelques Lagunas de haute altitude de la Sierra Nevada (Granada, Espagne). Ann. Limnol. 22(1): 53-63.

LÖFFLER, H., 1974. Harpacticiden (Crustacea, Copepoda) der Hochge birgsgewasser Andalusiens (Sierra Nevada, Spanien). Oster. Akademie der Wissenschaften. Mathem. naturw. Kl., Abt. I. 181 (7): 191-195.

MARTINEZ, R., 1975. First report on the limnology of the alpine lake La Caldera in the Penibetic Mountains (Sierra Nevada, Granada, Spain). Verh. Internat. Verein. Limnol. 19: 1133-1139.

MARTINEZ, R., 1977. Phytoplankton species, biomass and diversity in Lake La Caldera (Sierra Nevada, Granada, Spain). Acta Hydrobiol. 19: 95-107.

MIRACLE, R., 1978. Composición específica de las comunidades zooplanctónicas de 153 lagos de los Pirineos y su interés biogeográfico. Oecol. Aquat. 3: 167-212.

MORALES-BAQUERO, R., 1985. Estudio de las comunidades de rotiferos monogonontes de las lagunas de alta montaña de Sierra Nevada. Ph. D. Thesis. Universidad de Granada.

MORALES-BAQUERO, R., 1987a. Rotifer fauna of lakes and ponds over $2500 \mathrm{~m}$ above sea level in the Sierra
Nevada, Spain, with description of a new subespecies. Hydrobiologia 147: 97-101.

MORALES-BAQUERO, R., 1987b. Distribución de los rotíferos de la zona litoral de las lagunas de alta montaña de Sierra Nevada, España. Limnetica 3: 73-80

MORALES-BAQUERO, R., 1988. Body size variability of Euchlanis dilatata HERENBERG in high mountain lakes of Sierra Nevada (Spain). Arch. Hydrobiol. 112(4): 597-609

MORALES-BAQUERO, R., L.CRUZ-PIZARRO \& P. CARRILlO, 1986. Lagunas de alta montaña en Sierra Nevada: algunas características físicas y químicas. Act. II Simp. Agua Andal.: 413-424.

MORALES-BAQUERO, R., L. CRUZ-PIZARRO \& P. CARRILLO, 1988. Biomass and production of Euchlanis dilatata in high mountain lakes and ponds of Sierra Nevada (Spain). J. Plankton Res. 10(5): 1065-1075.

MORALES-BAQUERO, R., L. CRUZ-PIZARRO \& P. CARRILLO, 1989. Patterns in the composition of the rotifers communities from high mountain lakes and ponds in Sierra Nevada (Spain). Hydrobiologia 186/187: 215-221.

MOSELLO, R., 1984. Hydrochemistry of high altitude alpine lakes. Schweiz. z. Hydrol. 46: 86-99.

NUSSBAUM, F., 1931. Sur les formations des lacs de montagne dans les Pyrénées. Globe 70.

PECHLANER, R., 1967. Die Finstertaler Seen (Kühtai, Osterreich). II. Das Phytoplankton. Arch. Hydrobiol. 63: 145- 193.

PEJLER, B., 1965. Regional-ecological studies of of swedisf freshwater zooplankton. Zool. Bidr. Upps. 36(4): 407-515.

PEJLER, B., 1983. Zooplanktonic indicatory of trophy and their food. Hydrobiologia 101: 111-114.

PENNAK, R.W., 1955. Comparative limnology of eight Colorado mountain lakes. Univ. Col. Sud. Ser. Biol. 2: 75 pp.

PSENNER, R. \& U. NICKUS, 1986. Snow chemistry of a glacier in the Central Eastern Alps (Hintereisferner, Tyrol, Austria). Z. Gletscherkunde u. Glazialgeologie 22: 1-18

PUGA, E., 1971. Investigaciones petrológicas en Sierra Nevada occidental. Ph. D. Thesis. Universidad de Granada.

REYNOLDS, C., 1984. The Ecology of Phytoplankton. Cambridge University Press. Cambridge.

ROTT, E., 1988. Some aspect of the seasonal distribution of flagellates in mountain lakes. Hydrobiologia, 161: 159-170.

SAINZ-CANTERO, C.E. \& J. ALBA-TERCEDOR, 1991. Los Adephaga acuaticos de Sierra Nevada (Granada, España) (Coleoptera, Haliplidae, Gyrinidae, Dytiscidae). Boletin de la Asociación Española de Entomología, 15: (in press). 
SANCHEZ-CASTILLO, P., 1986. Estudio de las comunidades fitoplanctónicas de las lagunas de alta montaña de Sierra Nevada. Ph. D. Thesis. Universidad de Granada.

SANCHEZ-CASTILLO, P., 1987a. Un nuevo taxon del género Chromulina: C. nevadensis P.M. Sánchez sp. nov. Cryptogamie-Algologie 8(4): 235-240.

SANCHEZ-CASTILLO, P., 1987b. Estudio del ciclo biológico de Korshikoviella gracilipes (Lambert)Silva (Chlorococcales, Chlorophyta). Phycologia, 26(4): 496-500.

SANCHEZ-CASTILLO P., 1988. Algas de las lagunas de alta montaña de Sierra Nevada (Granada, España). Acta Bot. Malacitana, 13: 21- 52.

SANCHEZ-CASTILLO, P., 1991. Comentarios sobre la biología del fitoplancton. Alquihla, 19: 39-41.

SANCHEZ-CASTILLO, P. L. CRUZ-PIZARRO \& P. CARRILLO, 1989. Caracterización del fitoplancton de las lagunas de alta montaña de Sierra Nevada (Granada, España) en relación con las características fisico-químicas del medio. Limnetica, 5: 37-50

SCHABER, P., 1988. Rotatorien und Crustaceen in Tiroler Hochgebirgseen. In: PSENNER, R., K. ARZET, A. BRUGGER, J. FRANZOI, F. HIESBERGER, W. HONSIGERLEN-BURG, F. HORNER, U. NICKUS, P. PFISTER, P. SCHABER \& F. ZAPF; Versauerung von Hochgebirsseen in kristalline Einzugsgehieten Tirol und Karntens. Zustand,
Ursachen, Aushirkungen, Entwicklung. Wasserwirtschaft Wasservorsorge, Forschungsarheiten. Bundesmin. f. Landu. Forstwirtschaft, Wien: 209-258.

THOMASSON, K., 1956. Reflections on Artic and Alpine lakes. Oikos 7(1):117-143.

TONOLLI, L. \& V. TONOLLI, 1951. Osservazioni sulla biologia ed ecologia di 170 popolamenti zooplanctonici di laghi italiani di alta quota. Mem. Ist. Ital. Idrobiol. 6:53-136.

TRIFONOVA, I.S., 1989. Change in community structure and productivity of phytoplankton as indicators of lake and reservoir eutrophication. Arch. Hydr-ohiol. Beih. 33: 363-371.

WATHNE, B.M., R. MOSELLO, A. HENNIKSEN \& A. MARCHETTO, 1990. Comparison of chemical characteristics of mountain lakes in Norway and Italy. -In: JOHANNESSEN, M., MOSELLO, R. \& BARTH, H. (eds.): Acidification processes in remote mountain lakes. Air Pollution Research Report 20. Commission of the European Communities, Brussels, pp. 41-58.

ZOBRIST, J. \& J.I. DREVER, 1990. Weathering processes in alpine watersheds sensitive to acidification. In: JOHANNESSEN, M., MOSELLO, R. \& BARTH, H. (eds.): Acidification processes in remote mountain lakes. Air Pollution Research Report 20. Commission of the European Communities, Brussels, pp. 149-161. 